\title{
Research of Uncontrolled Landfills Impact on Environment in Georgia
}

\author{
Nugzar Buachidze, Khatuna Chikviladze, George Kordzakhia, Ekaterina Shubladze, \\ Lali Shavliashvili
}

Georgian Technical University, the Institute of Hydrometeorology, Tbilisi, Georgia

Email address:

mc.buachidze@yahoo.com (N. Buachidze), khatunac@hotmail.com (K. Chikviladze), giakordzakhia@gmail.com (G. Kordzakhia), e.shubladze@agruni.edu.ge (E.Shubladze),shavliashvililali@yahoo.com (L. Shavliashvili)

\section{To cite this article:}

Nugzar Buachidze, Khatuna Chikviladze, George Kordzakhia, Ekaterina Shubladze, Lali Shavliashvili. Research of Uncontrolled Landfills Impact on Environment in Georgia. American Journal of Environmental Protection. Vol. 5, No. 3, 2016, pp. 65-70.

doi: 10.11648/j.ajep.20160503.14

Received: April 21, 2016; Accepted: May 3, 2016; Published: June 7, 2016

\begin{abstract}
The inventory of the uncontrolled sites revealed uncontrolled landfill sites existing in the districts/regions of Georgia. The significant increase of soil and partially surface waters pollution level is developed due to the inefficient management of the different types of wastes. That significantly worsens social and economic conditions of life of the population. Integrated study of abovementioned issues is the scientific novelty of the research. The special research were carried to determine the pollution level in the samples collected, which due to the direct impact of these types of landfill sites on the surrounding areas, are often the main polluters of environment. The pollution conditions were studied based on modern methodology and techniques (ISO methods). The analysis revealed: hotspots existing in Georgia and necessary measures for prevention or/and mitigation measures for the concerned municipalities.
\end{abstract}

Keywords: Landfill, Wastes, Water and Soil Pollution, Heavy Metals, Biogenic Elements, Environment

\section{Introduction}

The proper management of the wastes is one of the important environmental problems of mankind [1-2]. Taking into consideration that in development countries exist the uncontrolled landfill sites it is obvious to create necessary measures for the policymakers for the elimination corresponding pollution risks [3-4].

There are a several uncontrolled landfill sites in Georgia. The countries policy after Soviet Union collapse was fully concentrated on the wastes that were remaining after Soviet troop's withdrawal. These were mainly the radioactive wastes as well as the chemical hazardous substances. These wastes were fully neutralized.

Still in Georgia the household and municipal wastes are existing. Such landfills are disposed country wide. They are often located near settlements, pastures and gorges. Even this time it is often impossible to transport wastes from these sites for final disposal or/and to clean up the territory [4]. Uncontrolled landfills remain on the places of disposal for years becoming one of the sources of pollution of the surrounding areas with different types of waste. Accordingly, the sanitary state of these areas is significantly deteriorated. It would be taken into consideration that nearby these sites the small rivers are existing and there is possibility to pollute their waters from landfills. These rivers can transfer this pollution to long distances. These hot spots create the necessity of complex study of pollution risks of the environment (land resources, surface waters, in some cases the underground water resources). Based on received results the necessary measures for assessment, prevention or/and reduction of underlying contamination risks would be created [5-9].

The problem is important as uncontrolled landfills may cause significant problems to population health.

\section{Study Area \& Methods}

Georgia is a transcontinental country, located along the dividing lines of Asia and Europe in the South Caucasus. Georgia is situated east of the Black Sea, south of Russia, north of Turkey and Armenia and northwest of Azerbaijan. 
Georgia covers an area of $69.700 \mathrm{~km}^{2}$.

Approximately $54 \%$ of the territory of Georgia is mountainous. The high mountains and plains occupy respectively $33 \%$ and $13 \%$ of country's territory. Respectively, the $70 \%$ of the territory is below the altitude of 1,700 meters [10].

Geography of Georgia is diverse: humid, subtropical lowlands and swamps; lakes and numerous rivers and soils; valleys; semi-deserts; hills; mountains covered by forests and glaciers [10].

Uncontrolled sites made a difficult problem to population especially to the people from the regions. The inventory of the uncontrolled sites was fulfilled. It deduced numerous uncontrolled landfill sites existing in the districts/regions of Georgia. In Fig. 1 is presented the disposition of uncontrolled landfill sites and its surroundings territories from where the testing (water and soil tests) where made.

Due to the mentioned problems the study includes almost all districts/regions of Georgia.

In Georgia the uncontrolled landfills, due to the inefficient management of the different types of wastes, ignoring the principles of sustainable development the significant increase of soil and partially surface waters pollution level is developed. That significantly worsens social and economic conditions of life of the population.

Integrated study of abovementioned issues is the scientific novelty of the research.

Research areas and problems has a broad variation to variety of materials and methods. The methodologies being used are detailed overviewed [11-18].

Shortly the used methods and devices are listed as follows:

1. Ion-selective chromatograph ICS-1000 (ISO 10304$1: 2007)$

2. Spectrophotometer SPECORD 205 (ISO 7150-1:2010);

3. Membrane filtration (ISO 9308-1; ISO 7899-2);

4. Plasma emission spectrometer ICP-MS;

5. Portable field device.

In order to carry out corresponding actions for accomplishment of tasks scheduled by the research it is necessary to carry necessary actions according to standards elaborated by International Standard Organization (acronym ISO).

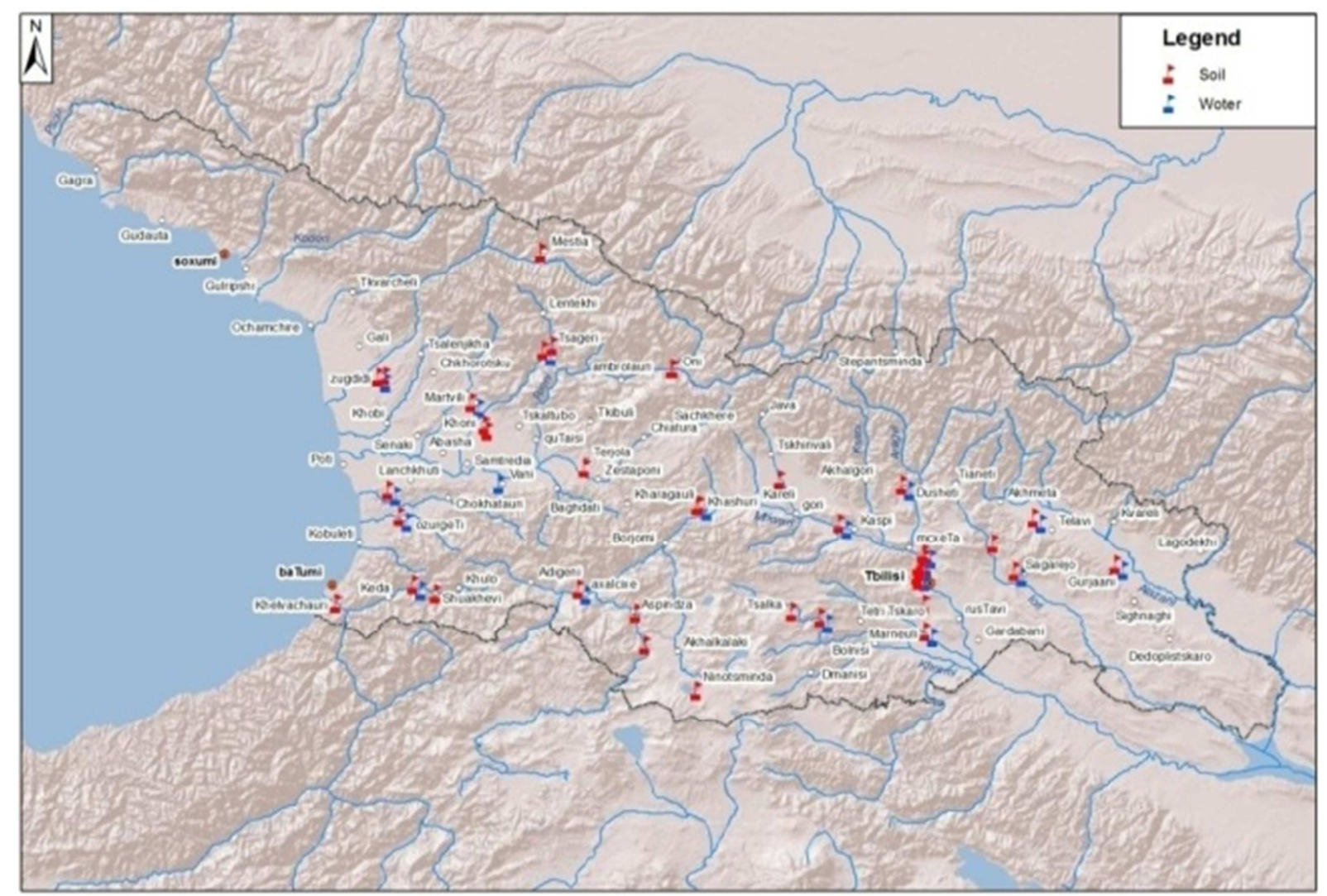

Fig. 1. The Disposition of testing points of Uncontrolled Landfill Sites in Georgia.

These measures with corresponding standards are:

- inventory, taking and transportation of soil analysis samples in the districts/regions under investigation implemented according to ISO 10381-1 and 10381-2;

- preparatory treatment and appropriate preparation (drying, disintegration, grinding, sieving etc.) of soil samples for chemical analysis carried based on ISO 11464 and ISO 565;
- sampling and transportation of water analysis samples implemented according to ISO 5667-4:1987 standards;

- determination of turbidity of water samples and suspended load using sedimentation method carried according to ISO 5667-17;

- determination of assimilated forms (N, P, K) in soil carried according to ISO 103041:2007 and 9964-3:2010.

The analyses have assessed some main ions, several forms 
of biogenic elements $\left(\mathrm{NO}_{2}^{-}, \mathrm{NO}_{3}^{-}, \mathrm{NH}_{4}^{+}, \mathrm{PO}_{4}{ }^{3-}\right)$ and heavy metals $(\mathrm{Cu}, \mathrm{Zn}, \mathrm{Pb}, \mathrm{Cd})$. In parallel with the abovementioned procedures, microbiological analyses (total coli forms, Fecal streptococci, and E. coli) of the pilot samples were performed, while at the sampling time, physicochemical properties of water were analyzed $(\mathrm{pH}$, temperature, electrical conductivity, dissolved oxygen, and salinity) using a portable device in the field at the sampling location (see Fig. 2). The all tests of the soil were taken (see Fig. 3) and transported to the leading two certified laboratories.

Accordingly, the objects of our research were comprehensively studied in order to collect not only hydro chemical but physicochemical and microbiological data as well.

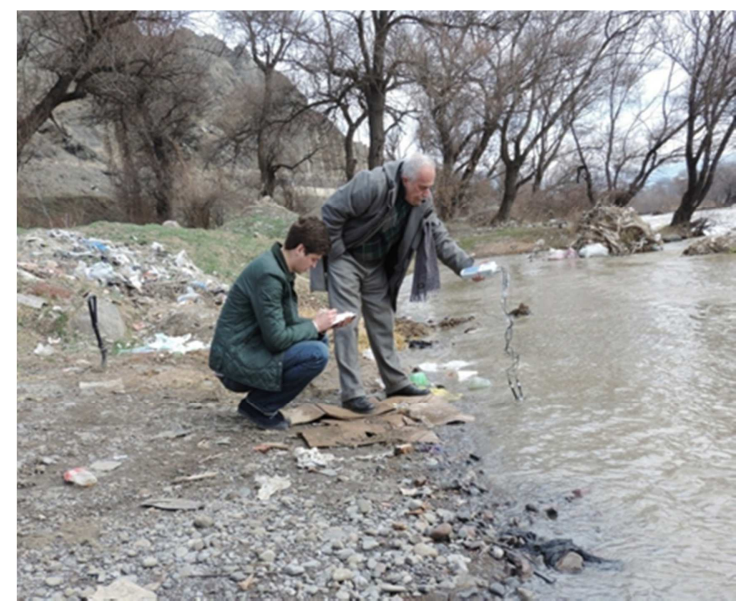

Fig. 2. Testing and Analyzing of the Physical- chemical Properties of Surface Waters in the Field.

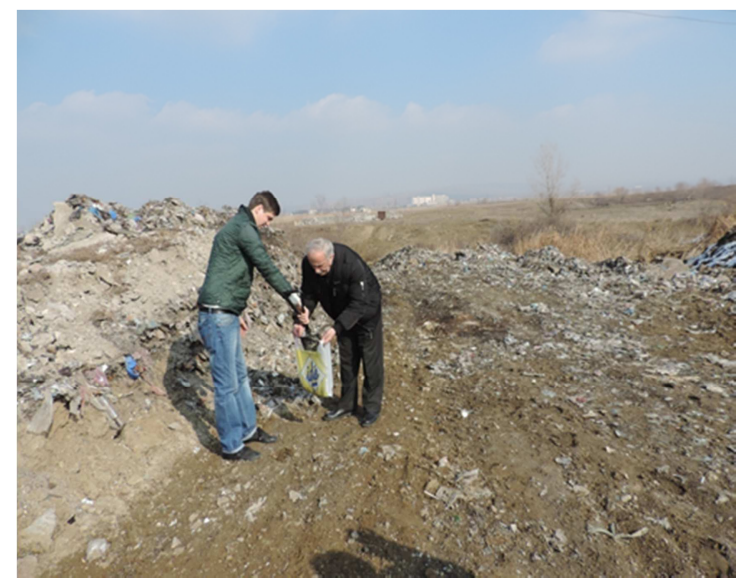

Fig. 3. The Soil Tests Gathered According to ISO 10381-1 and 10381-2.

\section{Results \& Discussions}

As it was mentioned above the samples (water, soil) were taken during 2013-2014 in illegal household waste landfill sites i.e. at the sampling location (Fig. 2-3) and further analyzed in laboratories.

By using proven modern methodology and techniques (ISO methods), the laboratories have assessed the pollutants in the samples collected, which due to the direct impact of these types of landfill sites on the surrounding areas, are often the main polluters of environment. Based on these analysis the amounts of these polluters are determined i.e. some main ions, several forms of biogenic elements $\left(\mathrm{NO}_{2}^{-}\right.$, $\left.\mathrm{NO}_{3}{ }^{-}, \mathrm{NH}_{4}{ }^{+}, \mathrm{PO}_{4}{ }^{3-}\right)$, and heavy metals $(\mathrm{Cu}, \mathrm{Zn}, \mathrm{Pb}, \mathrm{Cd})$. The carried microbiological analyses give possibility to define the exact amounts of total coli forms, fecal streptococci, and E. Coli. At the same time at the sampling locations physicochemical properties of water were analyzed $(\mathrm{pH}$, temperature, electrical conductivity, dissolved oxygen, and salinity) using a portable device in the field. Accordingly, the objects of our research were comprehensively studied in order to collect not only hydrochemical but physicochemical and microbiological data as well.

For each sampling location physical and geographical features: altitude, coordinates, approximate area of the landfill (coordinate system WGS-84. UTM), meteorological conditions were included. For performing this measurements portable GPC device is used. Based on these measurements is prepared related map (Fig. 1).

As it is seen from Fig. 1 the analyzed samples are taken from surrounding and nearby areas of uncontrolled sites western, eastern districts/regions of Georgia as well as the capital of Georgia c. Tbilisi.

In many cases, the concentrations of various polluting ingredients determined from the soil and water samples analyzes exceeded the maximum permissible concentrations, e.g., in the Kakheti region (Eastern Georgia).

In Fig. 4. The biogenic elements concentrations in the soil samples collected in the districts: Sagarejo, Gurjaani, Ikalto, Gombori (Kakheti Region) are presented. In Fig. 5. lead concentration in the soil samples collected in the Districts: Sagarejo, Gurjaani, Ikalto, Gombori (Kakheti Region) are shown.

High levels of pollution of lead and biogenic elements are revealed in Sagarejo (Fig. 4-5).

Microbiological analysis of the results revealed the significance of content of the leakage water of uncontrolled landfill site in the village of Metekhi (Eastern Georgia). Based on the research outputs in Fig. 6 the total coli form concentrations in the water samples collected from the Suramula River and Metekhi village landfill wastewater are presented.

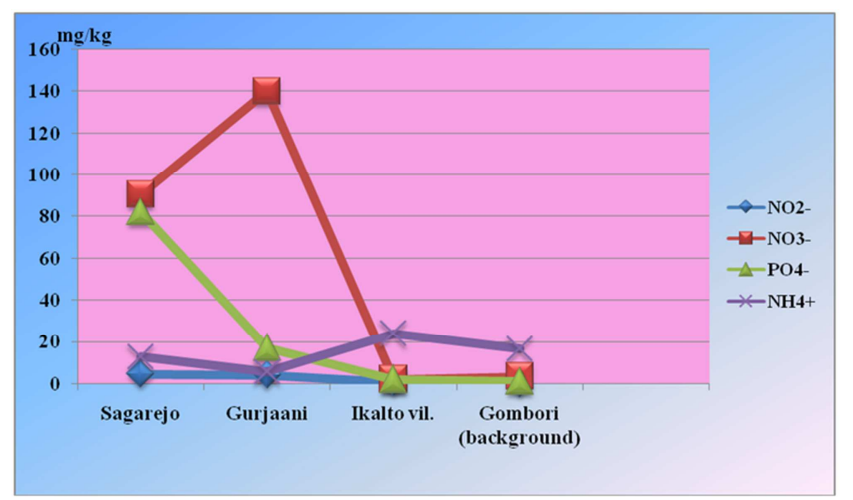

Fig. 4. The Biogenic Elements Concentrations in the Soil Samples Collected in the Districts: Sagarejo, Gurjaani, Ikalto, Gombori (Kakheti Region). 


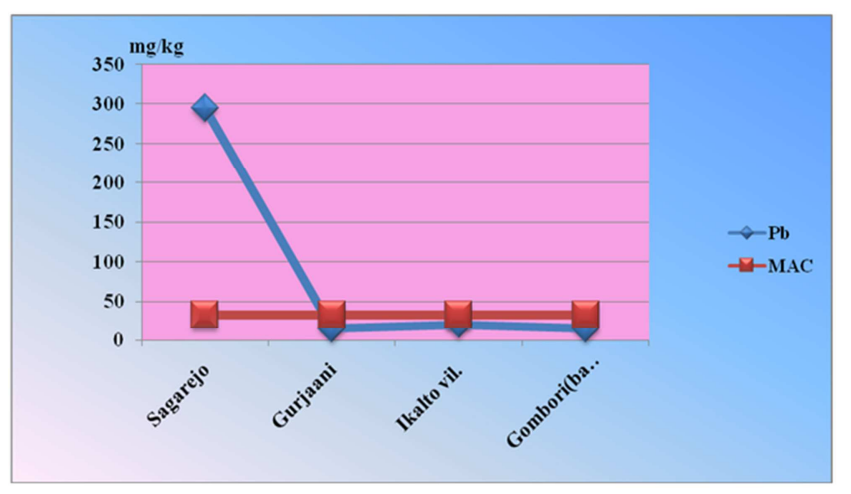

Fig. 5. The Lead Concentrations in the Soil Samples Collected in the Districts: Sagarejo, Gurjaani, Ikalto, Gombori (Kakheti Region).

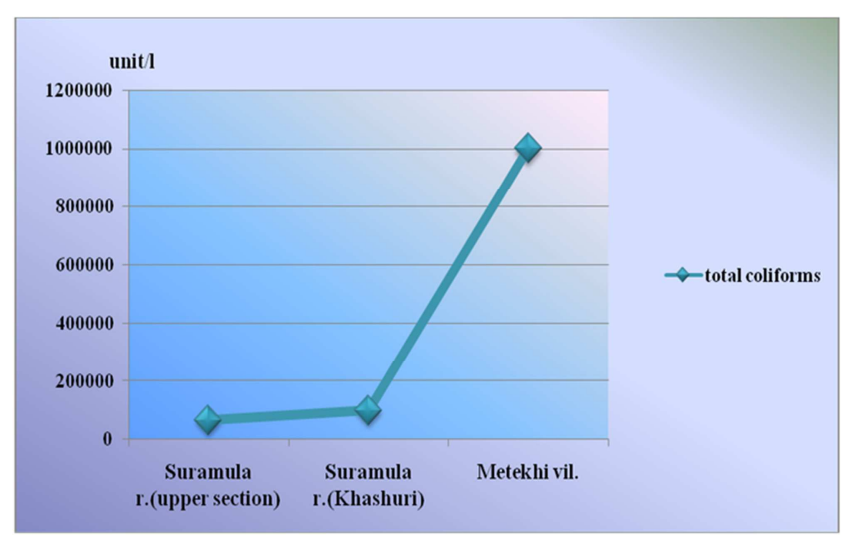

Fig. 6. The Total Coli Form Concentrations in Water Samples Collected from the Suramula River and Metekhi Village Landfill Wastewater.

As determined each liter of this water contains million units total coliform. This means that the infiltration of leakage water to the river Kura (Eastern Georgia) and which is used by pets is very dangerous for the rural population.

It would be noted that based on our recommendations the municipality of this site cleaned the territory.

The analysis performed for the soil samples gathered in the districts and towns of region Kvemo Kartli (Eastern Georgia): Marneuli, Kumisi, Bediani showed (see Fig. 4-5) that the pollution for the city Marneuli is very high. Comparison with MAC defines that in Kumisi the concentration of the carcinogenic heavy metals in the soil, namely lead amount is below MAC and cadmium is slightly more than MAC. The same comparison for the Bediani shows that the amounts of these metals are a little more than corresponding MACs and for the city Marneuli these characteristics are significantly higher than corresponding values of MACs.

It would be noted that the samples were taken from the vicinity of the landfill located nearby the city center. The analysis has revealed that the value of cadmium concentration is 2.5 times more than corresponding MAC value and the lead concentration is almost 5 times more than the related MAC.

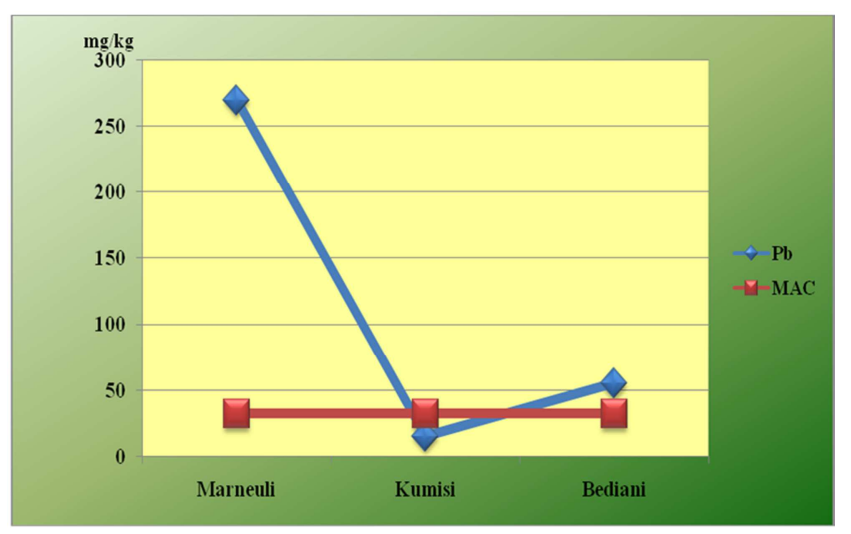

Fig. 7. The lead Concentrations in the Soil Samples Collected in the districts and towns: Marneuli, Kumisi, Bediani (Kvemo Kartli Region).

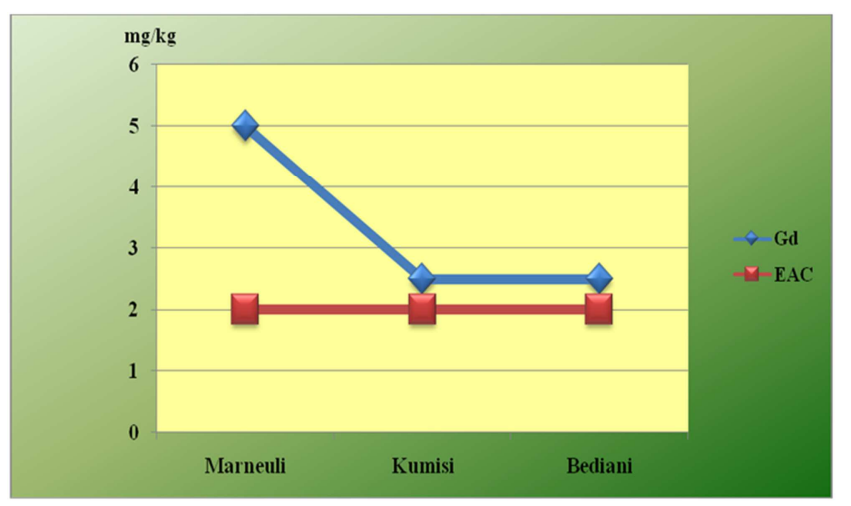

Fig. 8. The Cadmium Concentrations in the Soil Samples Collected in Kvemo Kartli.

The received results show that very different results are obtained for the West and East Georgia. The analysis of the water and soil samples showed that the territories and water bodies adjacent to the landfills located in western Georgia are relatively less polluted than similar areas in the East Georgia.

To prove this result the outputs of comparative analysis of the average results of the pollution characteristics for all three regions (West and East Georgia, the outskirts of c. Tbilisi) can be placed.

In Fig. 9-11 the copper, lead and zinc concentrations in the soil samples collected in Eastern Georgia, Western Georgia and the outskirts of Tbilisi are presented.

Analyses of these figures show that for the copper values content are higher than EAC values for the East Georgia and less than EAC for the West Georgia and outskirts of Tbilisi.

The corresponding analyses for the lead concentration in the soil samples revealed that lead concentrations values for East Georgia (almost everywhere) are higher than MAC and less than EAC or comparable with it for the West Georgia and outskirts of Tbilisi.

The corresponding analyses for the zinc concentration in the soil samples revealed that zinc concentrations values for East Georgia (almost everywhere) are higher than EAC and less than EAC or comparable with it for the West Georgia and outskirts of Tbilisi. 


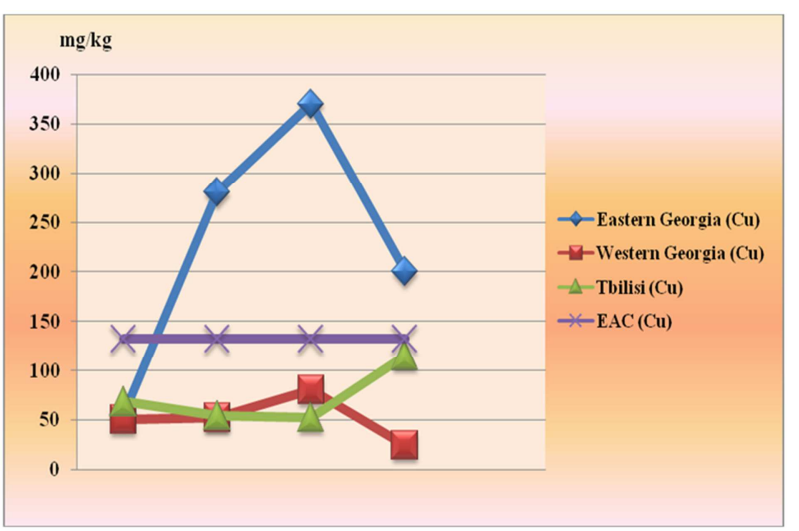

Fig. 9. The Copper Concentration in the Soil Samples Collected in Eastern Georgia, Western Georgia and the Outskirts of Tbilisi.

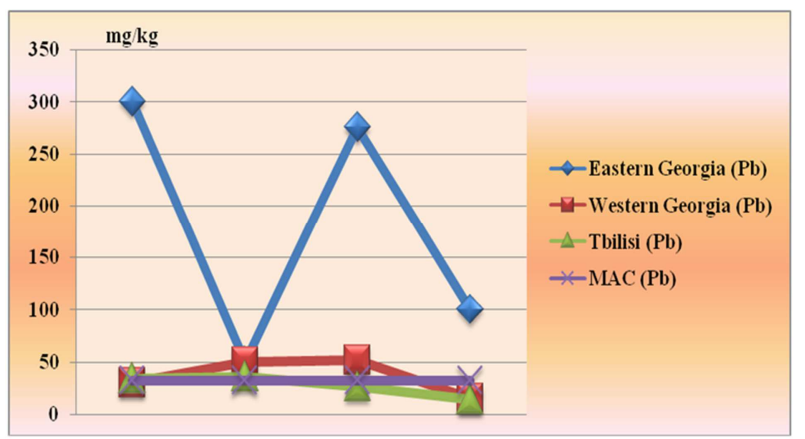

Fig. 10. The Lead Concentration in the Soil Samples Collected in Eastern Georgia, Western Georgia and the Outskirts of Tbilisi.

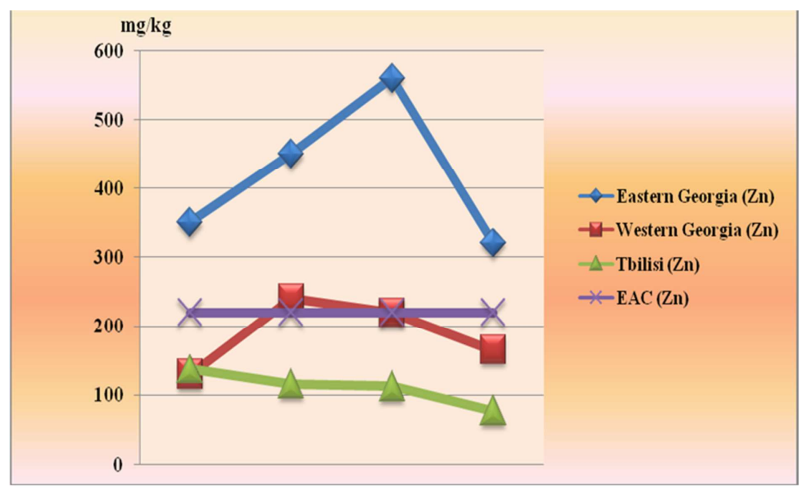

Fig. 11. The Zinc Concentration in the Soil Samples Collected in Eastern Georgia, Western Georgia and the Outskirts of Tbilisi.

It can be concluded that the most intensive anthropogenic impact on the surrounding areas of the uncontrolled landfill sites is observed in East Georgia and much less for the Western Georgia and the outskirts of Tbilisi.

Based on the performed research and analysis of the results obtained, it can be concluded that uncontrolled landfill sites play a significant role in the pollution process of the environment (water, soil, air). From the polluting components, we studied content of carcinogenic elements such as copper and cadmium and the amount of E. coli and Fecal streptococci concentrations and it is revealed that these concentrations often exceeds the MAC values.

Based on this analysis can be concluded that uncontrolled landfill sites not only pollute the surrounding areas and the environment, in general, but they create a significant hazard conditions for human health. Accordingly, the uncontrolled landfill sites should be immediately freed from wastes.

\section{Conclusion}

There are a several uncontrolled landfill sites in Georgia. The country's policy after Soviet Union collapse was fully concentrated on the wastes that were remaining after Soviet troop's withdrawal. These were mainly the radioactive wastes as well as the chemical hazardous substances. In addition to it the household and municipal wastes are existing. Such landfills are disposed country wide. There are a several uncontrolled materials and substances that create the high level of pollution and impact on surrounding territories. One of the main purpose of such conditions is that in Georgia are not designated the governmental bodies by the legislation responsible for the safe storage of hazardous wastes.

In different regions of Georgia numerous uncontrolled landfill sites exists. They are often located near settlements, pastures and gorges. Even this time it is often impossible to transport wastes from these sites for final disposal or/and to clean up the territory. Taking into consideration that nearby these sites the small rivers are running the water of them could be contaminated. These rivers can transfer this pollution to long distances. These hot spots create the necessity of complex study of the risk of pollution of the environment (land resources, surface waters, in some cases the underground water resources).

The study considers almost all districts/regions of Georgia.

In order to carry out corresponding actions for accomplishment of tasks scheduled by the research it is necessary to carry necessary actions according to ISO standards. Undertaking measures are:

- inventory, taking and transportation of soil analysis samples in the districts/regions under investigation based on ISO 10381-1 and 10381-2;

- preparatory treatment and appropriate preparation (drying, disintegration, grinding, sieving etc.) of soil samples for chemical analysis based on ISO 11464 and ISO 565;

- sampling and transportation of water analysis samples implemented according to ISO 5667-4:1987;

- determination of turbidity of water samples and suspended load using sedimentation method based on ISO 5667-17;

- determination of humus in soil samples implemented using colorimetric method (at a depths of 0-10, 10-20 and 20-30 cm);

- determination of assimilated forms (N, P, K) in soil carried according to ISO 103041:2007 and 9964-3:2010.

By using proven modern methodology and techniques (ISO methods), the laboratories have assessed the pollutants in the samples collected, which due to the direct impact of these types of landfill sites on the surrounding areas, are often the main polluters of environment. Based on these analysis the amounts of these polluters are determined i.e. 
some main ions, several forms of biogenic elements $\left(\mathrm{NO}_{2}^{-}\right.$, $\left.\mathrm{NO}_{3}{ }^{-}, \mathrm{NH}_{4}{ }^{+}, \mathrm{PO}_{4}{ }^{3-}\right)$, and heavy metals $(\mathrm{Cu}, \mathrm{Zn}, \mathrm{Pb}, \mathrm{Cd})$. The carried microbiological analyses give possibility to define the exact amounts of total coli forms, fecal streptococci, and E. Coli. At the same time at the sampling locations physicochemical properties of water were analyzed $(\mathrm{pH}$, temperature, electrical conductivity, dissolved oxygen, and salinity) using a portable device in the field. Accordingly, the objects of our research were comprehensively studied in order to collect not only hydrochemical but physicochemical and microbiological data as well.

The received results allow concluding:

- The pollution is different for the West and East Georgia. The analysis of the water and soil samples showed that the territories and water bodies adjacent to the landfills located in western Georgia are relatively less polluted than similar areas in the East Georgia;

- In Kakheti region (East Georgia) concentrations of various polluting ingredients (heavy metals, biogenic elements) determined from the soil and water samples exceeded the maximum permissible concentrations;

- In East Georgia are revealed heavy metals and total coliform high concentrations. The pollution by cadmium in c. Marneuli (Qvemo Kartli) and contamination by coliform forms in the water in vil. Metekhi (Shida Qartli Region) would be noted.

Based on the performed research and analysis of the results obtained, it can be said that uncontrolled landfill sites play a significant role in the pollution process of the ecosystems (water, soil, air). From the polluting components, we have assessed carcinogenic elements such as copper and cadmium as well as E. coli and Fecal streptococci the concentration of which - in our case-very often exceeds the Maximum Allowable Concentrations. All this suggests that the uncontrolled landfill sites not only pollute the surrounding areas and the environment, in general, but they represent rather create a significant hazard to human health. Accordingly, the surrounding areas with high levels of pollution should be immediately freed from such landfill sites.

\section{Acknowledgment}

The research is carried out based on Swedish Government financial support in frames of the project "Cleaning Georgia" in 2013-2015.

\section{References}

[1] European Environment Agency, 2013, "Municipal Waste Management in Germany".

[2] Ministry of Environment of Japan, 2012, "Solid Waste Management and Recycling Technology in Japan".

[3] Milios, Leonidas, Christian Fisher, and Andrea Rispo, 2014, "How Existing Municipal Solid Waste Data in ENPI East Countries Can Be Used for the Development of Waste Indicators".
[4] Cleanup Georgia, 2012, "Report on Municipal Solid Waste Management in Georgia".

[5] Kumar, D., and Alappat, B. J., "A technique to quantify landfill leachate pollution", In: Proceedings of the Ninth International Landfill Symposium, Cagliari, Italy, Paper no. 400, 2003.

[6] APHA, "Standard methods for examination of water and wastewater", 21st edition, American Public Health Association, Water Environment Federation Publication, Washington, DC., 224p. 2005.

[7] Halim, A. A., Aziz, H. A., Johari, M. A. M., Ariffin, K. S., and Adlan, M. N., "Ammoniacal nitrogen and COD removal from landfill leachate using a composite adsorbent: fixed bed column adsorption performance", Journal of Hazardous Materials, Vol. 175 (1-3), pp. 960-964, 2010.

[8] Youcai, Z., Jianggying, L., Renhua H., and Guowei, G., "Long Term Monitoring and Prediction for Leachate Concentrations in Shaghai Refuse Landfill”, Journal of Water, Air and Soil Pollution, Vol. 122, pp. 281-297, 2000.

[9] Fronczyk, J. and Garbulewski, K. "Selection of material suitable for permeable reactive barriers in the vicinity of landfills," Department of Geotechnical Engineering, Warsaw University of Life Sciences, Land Reclamation, Vol. 41, pp. 39, 2009

[10] L. Maruashvili (1971) - Physical Geography of Georgia. Tbilisi. 260 p. (in Georgian).

[11] Kumar D. and Alappat, B. J., "Selection of the appropriate aggregation function for calculating leachate pollution index", ASCE Practice Periodicals of Hazardous, Radioactive and Toxic Wastes, Vol. 8 (4), pp. 253-264, 2004.

[12] G. S. Fomin. Voda: Kontrol ximicheskoi, bakterialnoi i radiacionnoi bezopasnosti po mejdunarodnim standartam. Ensiklopedicheski spravochnik, «Protektor», M., 2010. (Russ.)

[13] G. S. Fomin. Pochva: Kontrol kahestva i ekologiheskoi bezopasnosti po mejdunarodim standartam. Spravochnik. «VNIIstandart», M., 2000. (Russ.)

[14] Gidroximicheskie pokazateli sostoyniy okrujaiushei sredi. /Pod red. T. V. Gusevoi/- M,: FORUM: INFRA- M, 2010. (Russ.)

[15] Dr. Viroj Wiwanitkit. Waste landfill site fire crisis in Thailand; sulfur dioxide pollution and estimation of cancer risk. South Asian J Cancer. 2014 Jul-Sep; v. 3 (3): 185-186.

[16] Han, J. "The Systematization of Waste Landfill Site Selection Process utilizing GIS." Journal of Korean Society for Geospatial Information System, 10.7319/kogsis.2014.22.3.021, 21-30.

[17] Nomohanran, O. (2015). "Assessment of site suitability for landfill construction in Gbekele, Nigeria." Journal of the Geological Society of India, 10.1007/s12594-015-0271-y, 745-752.

[18] Hamzeh, M., Ali Abbaspour, R., and Davalou, R. (2015). "Raster-based outranking method: a new approach for municipal solid waste landfill (MSW) siting." Environmental Science and Pollution Research, 10.1007/s11356-015-4485-8, 12511-12524. 